\title{
Effects of Biodegradable Detergents in the Accumulation of Lipofuscin (Age Pigment) in Gill and Liver of Two Neotropical Fish Species
}

\author{
Efectos de Detergentes Biodegradables en la Acumulación de Lipofuscina (Pigmento \\ de Envejecimiento) en Branquias e Hígado de Dos Espécies de Peces Neotropicales
}

\author{
Bruno Fiorelini Pereira*; Anderson Luis Alves**; José Algusto Senhorini" ${ }^{* * *}$; Rita de Cássia \\ Gimenes de Alcântara Rocha***; Dimítrius Leonardo Pitol ${ }^{* * * *}$ \& Flávio Henrique Caetano*****
}

PEREIRA, B. F.; ALVES, A. L.; SENHORINI, J. A.; ROCHA, R. C. G. A.; PITOL, D. L. \& CAETANO, F. H. Effects of biodegradable detergents in the accumulation of lipofuscin (age pigment) in gill and liver of two neotropical fish species. Int. J. Morphol., 32(3):773$781,2014$.

SUMMARY: Currently there is a growing concern, in both population and governments, to identify the effects of substances commonly disposed of into rivers and lakes, on aquatic fauna and flora. Thus the objective of the present study was to verify effects of biodegradable detergents and water from an urban lake on gills and liver of two neotropical fish species of great economic importance, Astyanax altiparanae and Prochilodus lineatus. In order to do so, lipofuscin, also called the ageing pigment, was used as bioindicator. After one and five months of experiment both tissues accumulated this pigment. These data are discussed from physiological points of view, related with lipid peroxidation and mitochondrial damage.

KEY WORDS: Lipofuscin; Liver; Gill; Prochilodus; Astyanax.

\section{INTRODUCTION}

According to Arking (2008) a summary of the theory of residue accumulation proposes that cellular ageing is caused by an agglomeration of intracellular residual products that cannot be destroyed or eliminated, except by cellular division. It is common knowledge that postmitotic cells, such as neurons and cardiac muscle cells, accumulate irregularly shaped, lipid rich yellowy brown cytoplasmic granules during ageing. These granules, called lipofuscin granules, were first observed in 1842 and its relation to ageing began to be discussed in 1886; since then, numerous studies were carried out in an effort to understand possible mechanisms responsible for lipofuscin formation and accumulation and elucidate its role in ageing processes (Arking).

Lipofuscin is a product of lipid peroxidation and evidence of oxidative lesion, since it is an end product that results from non-enzymatic cellular glycosylation and incomplete degradation of damaged mitochondria that could not be degraded by lysosomal hydrolases nor be exocited (Silva \& Silva, 2005; Schutt et al., 2003; Kishi et al., 2008). Accumulating over time in post-mitotic cells, these residues are not degraded during cell division and can develop into diseases. These lipofuscin granules are usually surrounded by two membranes, do not contain lysosomal enzymes (Terman \& Brunk, 1998; Kodama et al., 2005) and are formed by materials initially hijacked by autophogosomes (Terman \& Brunk). Although these autophagosomes end up fusing with a primary or secondary lysosome (Peixoto et al., 2002). Both lipofuscin precursors and their mature forms, encompassed by vesicles as described by Terzibazi et al. (2008), can be found in several organisms and are identified by the remarkable trait of autofluorescence.

Currently, increased amounts of pollutants dumped into aquatic environments reinforce the importance of chemical and biological monitoring of these ecosystems,

* Universidade Federal do Oeste da Bahia, Barreiras, Bahia, Brazil.

** EMBRAPA, Palmas, Tocantins, Brazil.

*** ICMBio/CEPTA, Pirassununga, São Paulo, Brazil.

***** Faculdade de Odontologia de Ribeirão Preto, FORP/USP, Ribeirão Preto, São Paulo, Brazil.

******* Universidade Estadual Paulista «Júlio de Mesquita Filho» - UNESP -Campus de Rio Claro, São Paulo, Brazil. 
therefore, biomarkers have become a useful tool (Pinto et al., 2010). Several tests based on stress biomarkers have been used to identify the effects of pollutants on aquatic organisms (Viarengo et al., 2007). These markers reveal modifications in several biological parameters, including lysosomal membrane stability, lipid content and lipofuscin presence on cells (Viarengo et al.).

Many of the pollutants disposed of into aquatic environments have been proven to induce formation of free radical in cells. These radicals are usually neutralized and eliminated by antioxidant elements produced by the cell itself and several studies have confirmed that both fish and mollusks are sensitive to these contaminants (Cajaraville $e t$ al., 2003). Some of these pollutants can cause proliferation of peroxisomes, which carry antioxidant enzymes that eliminate free radicals.

Individuals of Astyanax and Prochilodus genera are widely distributed in South American water basins and are of great ecological and financial value, bearing in mind their use as a food source for various populations. Because they are found almost throughout Brazil, these genera have been used as bioindicators of rivers and lakes.

Considering the growing concerns regarding anthropogenic impacts on aquatic fauna, the present study proposes to test the use of lipofuscin as an environmental stress marker. For such purposes, effects of disturbed environments on the accumulation of this substance were analyzed in native fish to better understand the extent of damages caused by contaminants on neotropical species.

\section{MATERIAL AND METHOD}

Experimentation. Macrophage proliferation is associated to natural events such as ageing and fasting, however, it can also be induced by exposure to pollutants (Couillard \& Hodson, 1996). So much so that several studies report not only their proliferation, but also pigment accumulation, even though researchers do not usually take the age of specimens into consideration. Despite the fact that many of the studies found in literature relate lipofuscin inclusions to ageing, when establishing causal links between exposure to pollutants and lipofuscin formation, the age factor is, once again, usually neglected. Therefore, so that there were no errors related to age variance, the specimen's age was standardized and the experiment begun with four-monthold A. altiparane specimens and two-month-old P. lineatus specimens, ages at which the species already present ideal body size to allow sampling.
In order to obtain the specimens, Astyanax altiparanae and Prochilodus lineatus matrixes were reproduced at the Fish Reproduction Laboratory of ICMBio/ CEPTA - Pirassununga - SP - Brazil. Sixty individuals of each species were divided into three groups: first, a control group, exposed to water from the artesian well at UNESP Campus - Rio Claro; second, a group exposed to a dilution of 10 different commercial brands of biodegradable detergent at 1ppm concentration; and third, a group that was kept on water from an urban lake (Lago Azul - Rio Claro - SP Brazil), proven to have been polluted by residues from residences, gas stations and small industries. This lake was used as an example that should characterize extremely anthropomorphized environments and could then be extrapolated to other similar situations.

The experiment lasted five months and two groups of samples were taken, the first after one month of experiment and the second at the end of it. Oxygen levels and temperature were controlled throughout the experiment and kept identical for all groups. All the experiment was replicated to guarantee the validity of results obtained.

Histological identification of lipofuscin. Several methods have been used to quantify lipofuscin, but the most reliable method is fluorescence-based microscopy, due to the fact that, although lipofuscin has yellowy-brown coloring, in histological and histochemical techniques such as Hematoxylin and Eosine and Schiff Periodic Acid technique (PAS), various other substances can be marked in a similar way. Pigmented macrophage accumulations are common in liver, spleen, kidney and occasionally in other organs of fishes, but one of the most common variations occurs in the liver, including during their reproductive cycle (Couillard \& Hodson; Jordanova et al., 2008). Macrophage accumulations contain basically four types of pigment: melanin, lipofuscin, ceroides and hemosiderin. These pigments can also be found in hepatocytes and other cells, forming aggregates similar to lipofuscin in coloring, which prevent its precise identification by histological techniques. Because it is the only pigment that presents autofluorescence, its precise identification can only be made by analyses based on this property.

Six individuals were sacrificed from each group and species in each sampling period. The animals were anaesthetized in benzocaine solution $(0.1 \mathrm{~g}$ benzocaine in 1 $\mathrm{mL}$ ethylic alcohol for each $100 \mathrm{~mL}$ deionized water) before being sacrificed. Gill and liver fragments from each species were removed, fixed in $10 \%$ formaldehyde according to Junqueira \& Junqueira (1983), dehydrated in alcohol and embedded in Sigma Paraplast. Sections of $7 \mu \mathrm{m}$ were obtained with a Leica RM2245 micotome. Slides were 
mounted in Entellan, observed under an Olympus - BX51 fluorescence microscope and analyzed and photographed with the help of DP - Controller software, using a $450-490$ nm light filter according to Peixoto et al.

Lipofuscin quantification. For lipofuscin variance analyses, 10 photographs of five sections of gills and liver of each individual were observed using ImageJ version 1.46e. Lipofuscin granules were isolated and their total area was quantified, so that the amount of lipofuscin could be identified in each tissue fragment analyzed.

Statistical analysis. Arithmetic means of lipofuscin area data generated by ImageJ for liver and gills of each individual were used for statistical analysis. To identify significant variance these data were submitted to Shapiro-Wilk's normality test and ANOVA/ Tukey or Kruskal-Wallis/Dunn's tests of variance depending on normality results.

Chemical analysis. To better comprehend obtained results, water samples from all test groups were analyzed at the Water Analysis Laboratory from the Department of Applied Geology at the Institute of Geosciences and Exact Sciences - UNESP - Campus - Rio Claro. Analyses for the following parameters were performed according to the Standard Methods for the Examination of Water and Wastewater:

Metals were determined by ICP-AES for the elements: $\mathrm{Mg}, \mathrm{Ca}, \mathrm{Sr}, \mathrm{Ba}, \mathrm{Cr}(\mathrm{t}), \mathrm{Mn}, \mathrm{Fe}, \mathrm{Co}, \mathrm{Ni}, \mathrm{Cu}, \mathrm{Zn}, \mathrm{Cd}$, $\mathrm{Si}, \mathrm{P}(\mathrm{t})$ and $\mathrm{Pb}$. Anions: $\mathrm{F}-, \mathrm{Cl}-, \mathrm{NO}^{2}, \mathrm{NO}^{3}, \mathrm{PO}^{4}, \mathrm{SO}^{4}, \mathrm{ClO}^{2}$, acetate and oxalate; and cations $\mathrm{Li}, \mathrm{Na}, \mathrm{NH}^{4}$ and $\mathrm{K}$, were determined by ionic chromatography. Conductivity, $\mathrm{pH}$, total alkalinity and carbohydrates were analyzed by potentiometric titration.

Linear alkyl benzene (LAS, the main component of biodegradable detergents) concentration was determined by chromatographic analysis on the premises of Global Análise \& Consultoria - São Carlos - SP - Brazil, with an Agilent Technologies 1200 series HPLC and fluorescence detector.

\section{RESULTS}

Lipofuscin identification. Lipofuscin granules were identified as fluorescent cytoplasmic inclusions, generally perinuclear. Intense reaction was also observed on blood vessels, due to erythrocyte autofluorescence. These markings were not considered for analysis.

Astyanaxaltiparanae. Control groups showed lipofuscin markings on both organs throughout the experiment.
However, when exposed to contaminants specimens presented an increase in the number of lipofuscin markings in both samples (one and five months).

In the liver, effects on granule amounts were striking on both contaminated treatments, bearing in mind the large number of cytoplasmic granules found when compared to controls (Fig. 1). These observations were statistically confirmed. Significant differences were found among individuals kept in lake water and in diluted detergents compared to control groups, after one month of experiment with $\mathrm{p}<0.05$ (Kruskal-Wallis/Dunn) and after five months with $\mathrm{p}<0.01$ (ANOVA/Tukey) (Table I).

In the gills, granules were found mainly on secondary lamellae cells for all experimental groups. The same pattern found for liver was observed for the gills throughout the experiment (Fig. 2). This was also confirmed by KruskalWallis/Dunn's test with $\mathrm{p}<0.05$ (Table I), showing greater amounts of lipofuscin in tissues exposed to pollutants.

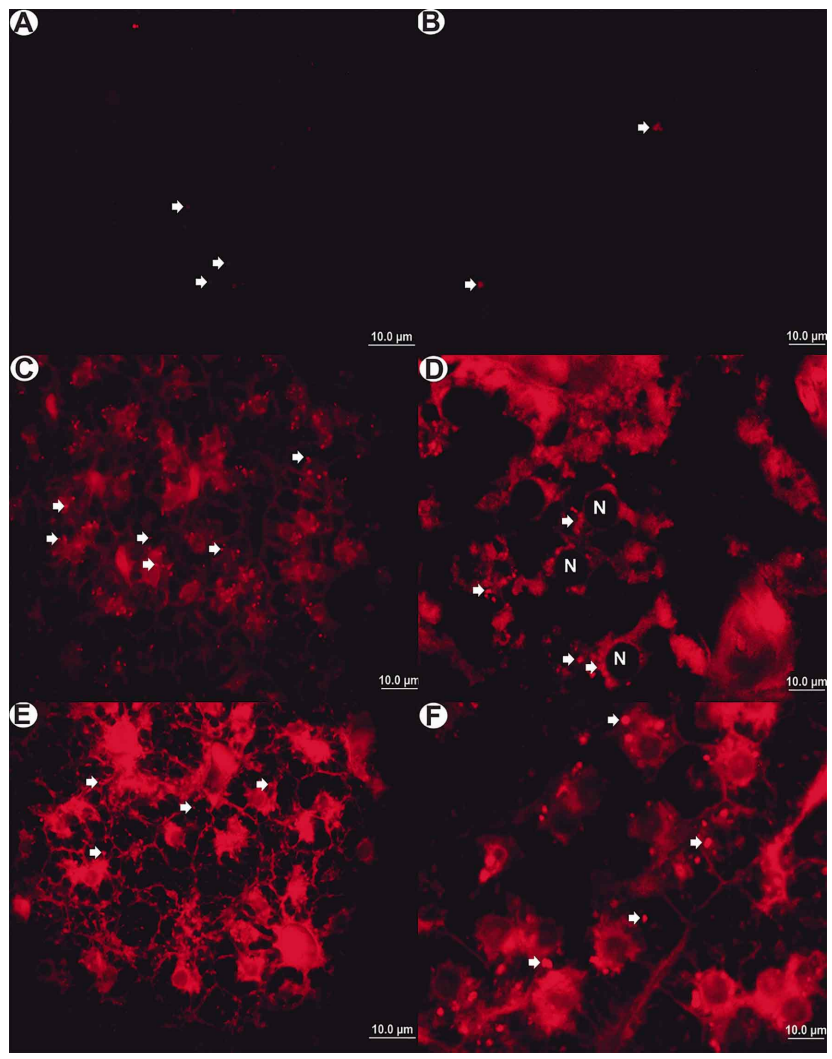

Fig. 1. A and B - general appearance of the liver of A. altiparanae observed under fluorescence microscopy (1 and 5 months, respectively). C and D - liver of A. altiparanae after exposure to detergent (1 and 5 months, respectively). E and $\mathrm{F}$ - liver of A. altiparanae after exposure to the water from the urban lake ( 1 and 5 months, respectively). Note the high concentration of lipofuscin granules (arrows) in the groups exposed to contaminants. $\mathrm{N}-$ nucleus. 


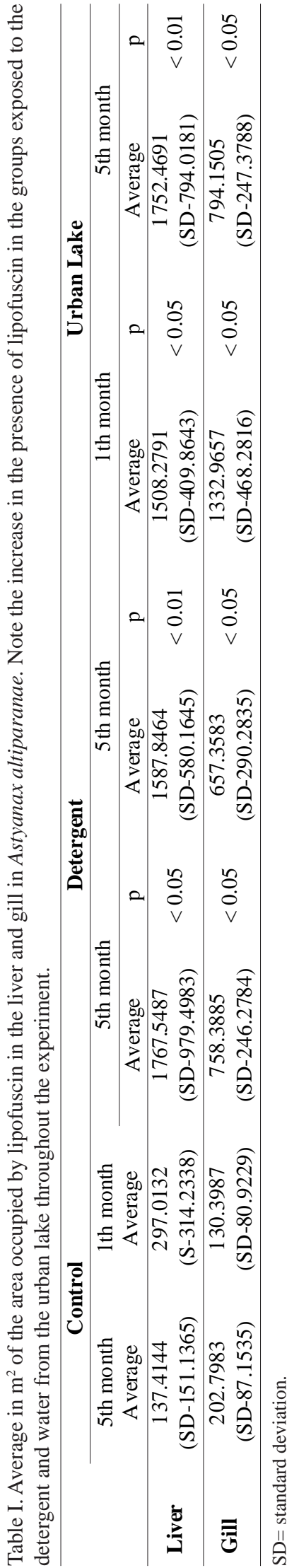

Prochilodus lineatus. Groups exposed to contaminants had significantly greater number of granules in the liver than that found for control groups (Fig. 3), with $\mathrm{p}<0.05$ for Kruskal-Wallis/Dunn's test.

Regarding gill analysis (Fig. 4), after one month of experiment there was an increase in lipofuscin granules amount in both contaminated treatments (Table II) with $\mathrm{p}<0.05$ (Kruskal-Wallis/Dunn). However, the data obtained after five months for groups exposed to detergent showed decreased amount of granules compared to control group (Table II) with $\mathrm{p}<0.05$ (Kruskal-Wallis/Dunn).
Fig. 2. A and B - general appearance of the liver of $\mathrm{A}$. altiparanae observed under fluorescence microscopy (1 and 5 months, respectively). $\mathrm{C}$ and D - liver of $\mathrm{A}$. altiparanae after exposure to detergent (1 and 5 months, respectively). E and F. liver of A. altiparanae after exposure to the water from the urban lake (1 and 5 months, respectively). Note the high concentration of lipofuscin granules (arrow) in the groups exposed to pollutants, except for detergent group after 5 months, were we found fewer granules, when compared with the control group.
Values of lipofuscin area of samples taken from groups exposed to lake water for 5 months were not presented because no animals survived for so long. Maximum survival was 35 days, shortly after the first samples were taken.

Results of chemical analysis of water. Water analysis revealed several modified parameters in both contaminated treatments, as shown in Table III. Regarding LAS concentration, $0.375 \mathrm{mg} /$ $\mathrm{L}$ of surfactant was found in in detergent dilution samples, and, $0.33 \mathrm{mg} / \mathrm{L}$ in lake samples. 


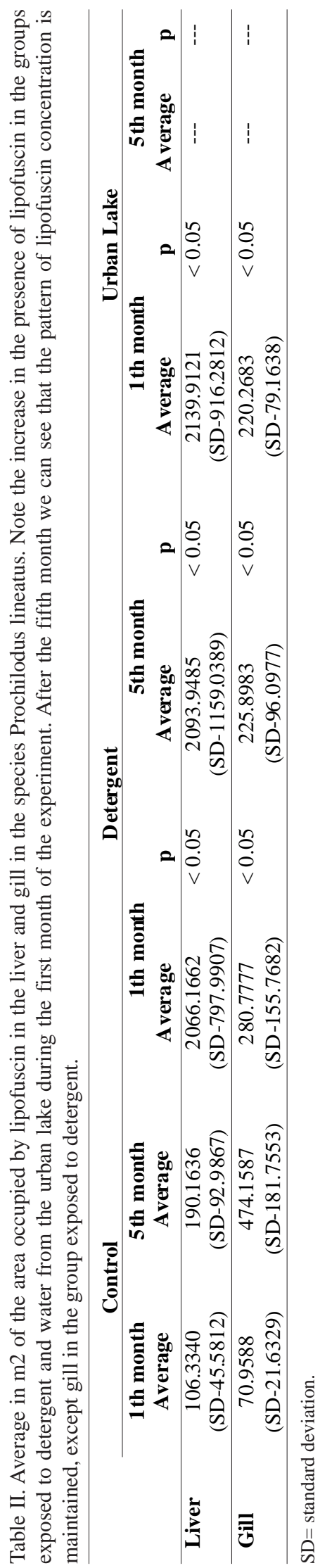

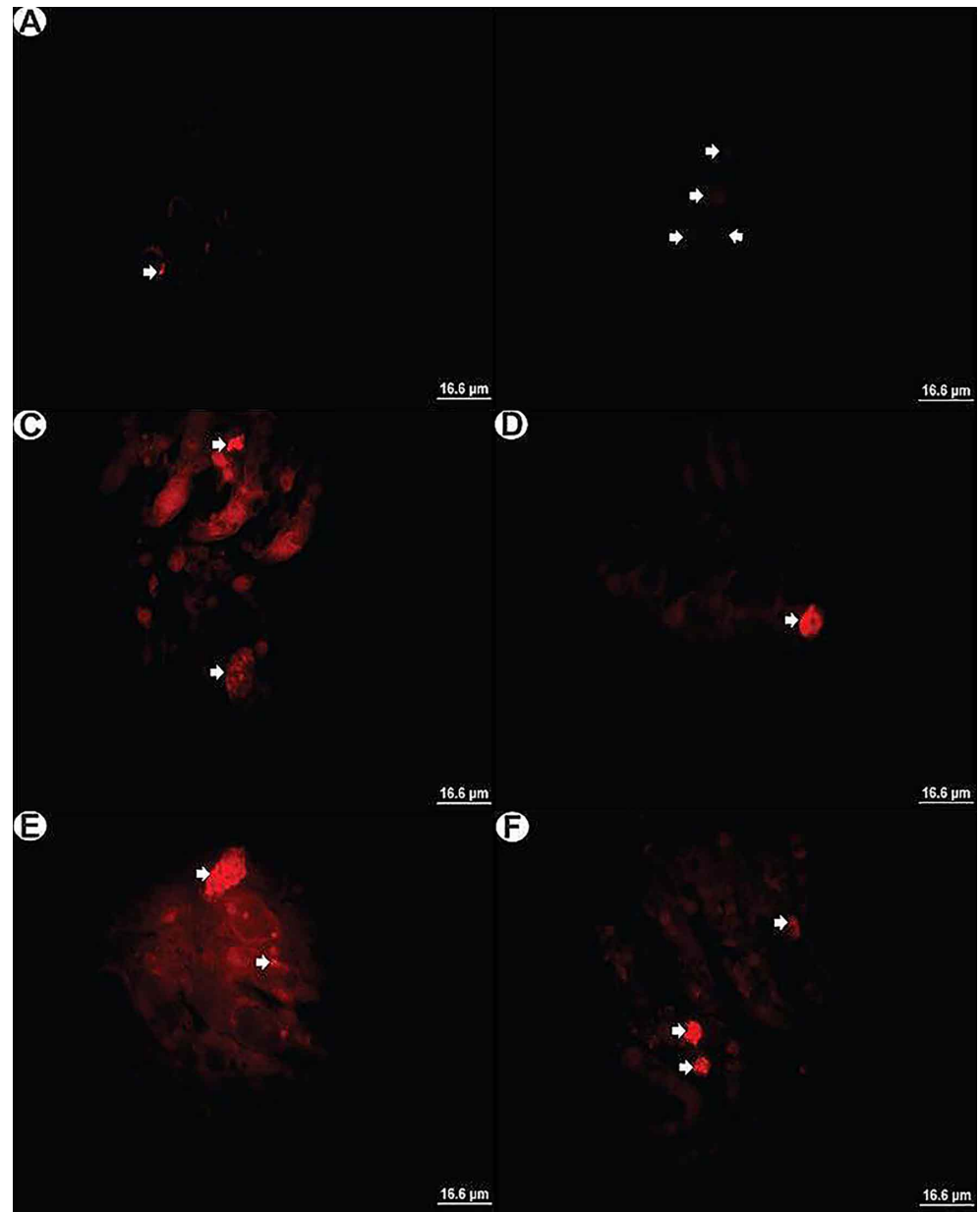

Fig. 3. A and B - general appearance of the gill of the species $P$. lineatus observed under fluorescence microscopy (1 and 5 months, respectively). C and D - gill of P. lineatus after exposure to detergent (1 and 5 months, respectively). E - gill of $P$. lineatus after exposure to the water from the urban lake (1 month). Note the high concentration of lipofuscin granule (arrowhead) in the groups exposed to contaminated water.

Table III. Major changes in water with detergent dilution and the Urban Lake. Note that the main difference compared with the control group are highlighted in bold.

\begin{tabular}{lccc}
\hline & Control & Detergent & Urban Lake \\
\hline $\mathrm{pH}$ & 5.39 & 6.04 & 7.17 \\
Conductivity $(\mu \mathrm{S} / \mathrm{cm})$ & 282 & 237 & 179 \\
\hline $\mathrm{Na}(\mathrm{mg} / \mathrm{L})$ & 8.56 & 5.56 & $\mathbf{1 6 . 7}$ \\
$\mathrm{NO}_{2^{-}}(\mathrm{mg} / \mathrm{L})$ & $<0.04$ & 1.15 & 0.86 \\
\hline $\mathrm{Ni}(\mathrm{mg} / \mathrm{L})$ & $<0.010$ & $\mathbf{0 . 0 6 6}$ & $<0.010$ \\
$\mathrm{~F}^{-}(\mathrm{mg} / \mathrm{L})$ & 0.25 & 0.23 & $\mathbf{0 . 4 0}$ \\
\hline $\mathrm{Cl}-(\mathrm{mg} / \mathrm{L})$ & 8.56 & 5.56 & $\mathbf{1 6 . 7}$ \\
$\mathrm{Fe}(\mathrm{mg} / \mathrm{L})$ & 0.021 & 0.029 & $\mathbf{0 . 1 6}$ \\
\hline
\end{tabular}




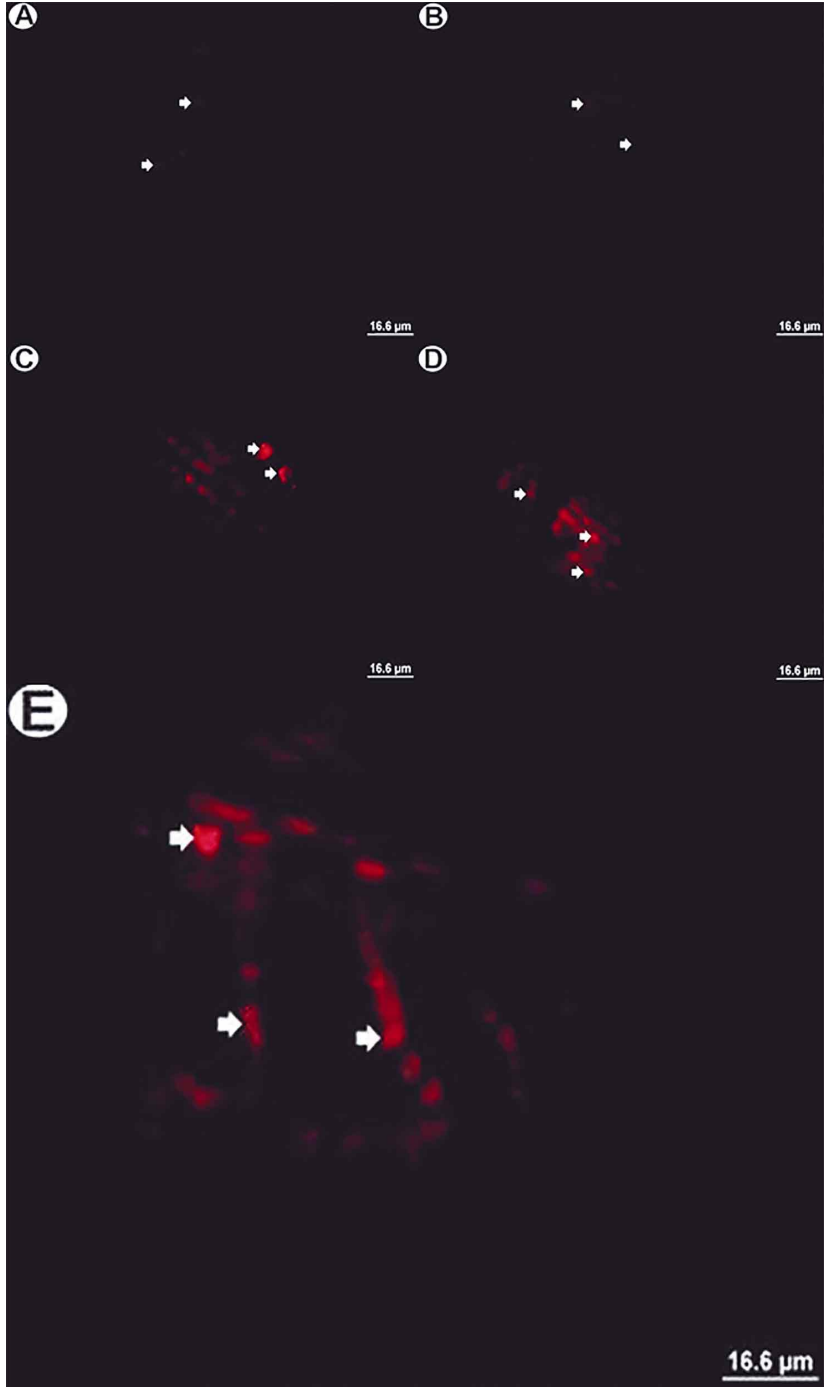

Fig. 4. A and B - general appearance of the gill of the species $P$. lineatus observed under fluorescence microscopy (1 and 5 months, respectively). C and D - gill of $P$. lineatus after exposure to detergent ( 1 and 5 months, respectively). E - gill of $P$. lineatus after exposure to the water from the urban lake (1 month). Note the high concentration of lipofuscin granules (arrows) in the groups exposed to contaminants. * - Erythrocyte.

\section{DISCUSSION}

Cytological and histological alterations in fish liver are considered early indications of toxic effects and are, therefore, widely used as biomarkers of damage caused by xenobiotics at sublethal concentrations (Au et al., 2004). According to these authors contaminants can generate free radicals, especially oxygen-reactive species that attack polyunsaturated lipids, leading to lipid peroxidation and consequent lipopigment production. Lipofuscin is composed of lipid polymers complexed with proteins and can be used as lipid peroxidation markers as well (Couillard \& Hodson). So much so, that studies have shown that lipid peroxidation rates are proportional to free radical concentration, thus, the greater the concentration, the higher the rate and high rates of lipid peroxidation result in macrophage recruitment in affected areas (Couillard \& Hodson).

Studies of effluents from cellulose industries demonstrated that cellular catabolism and lipid peroxidation increased in several tissues after the fish had contact with these contaminants (Couillard \& Hodson). These authors explain that this type of response can reduce food metabolism efficiency and affect growth or even survival of sensitive species in environments with low food availability. Other studies show that exposure to benzopyrene raises lipofuscin concentration in fish hepatocytes (Au et al., 2004). Therefore, our results are corroborated by other authors, bearing in mind that increased lipofuscin concentration was found both in liver and gills in both species after exposure to pollutants. As described, the formation of these inclusions is directly linked to lipid peroxidation, which is caused by increased levels of free radicals.

Quite a few researchers demonstrate effects of contamination on lipofuscin accumulation, such as Vaschenco et al. (2012), who showed that pollutants as well as anoxic environments, affect lipofuscin accumulation in mollusks; and Banni et al. (2009), who demonstrated that lipofuscin naturally accumulates with age in mollusks, but that the process can be accelerated by pollutants. Similar results can be found in studies by Radwan et al. (2010), Borucinska et al. (2009), Han \& Fang (2010), Machella et al., (2005) and Teh et al. (1997), for Thebapisana, Prionacae glauca, Xiphophorus helleri, Anguilla Anguilla and Lepomisauritu, respectively.

Oxidative stress occurs when antioxidant defenses are overpowered by pro-oxidative forces, therefore oxygen reactive species are not correctly released from cells (Banni et al.). Metals, such as copper and lead, stimulate lipid peroxidation and so do some organic compounds and, according to Banni et al. and Moore (1999) lipofuscin granules contribute to detoxification of metals, because they can form residual bodies with these elements and isolate them from the cytoplasm. There is a direct causal link between the presence of metals, such as iron, and lipofuscin accumulation in gonads of Strongylocentrotus intermedius, therefore decreased cellular antioxidant capacity is responsible for increased lipofuscin incidence (Vaschenco et al.). Similar results were obtained by Hödl et al., (2010) in Helix pomatia, after exposure to copper. 
Water analysis showed metals such as nickel in detergent dilutions and iron in lake waters, what led us to believe that these elements may be directly linked to lipofuscin formation due to the fact that they are proven generators of free radicals and must be isolated in the cytoplasm by lipofuscin granules.

In addition to containing non-digested membranes and poorly formed proteins, lipofuscin inclusions can accumulate substances that if dissolved in the cytoplasm, would be highly toxic (Zhao et al., 2011), so it is best that the granules stay packet and their contents, isolated. However, this storage can in long term, inhibit lysosomal functions and accelerate lipofuscin deposition. This data may be directly correlated to modifications detected in the gills, since they are in direct contact with the environment and exchange substances with it, including contaminants present in the water. LAS surfactant found in detergents is water soluble, what must increase its cytoplasmic solubility and force the cell to isolate it when the gills absorb it from the environment.

Lipopigment accumulation raises susceptibility to oxidative stress in humans, leading to damage and disturbances to lysosomal systems, decreasing adaptability and increasing cell death rates (Au et al.). In fish these pigments affect vital cell functions, what can decrease adaptability to the environment, what was demonstrated by Ding et al. (2010) in an experiment which shows that crescent lipofuscin accumulation is accompanied by an increase in apoptotic cell number in several tissues of Oryzias latipes; and Agius \& Roberts (2003), who showed a correlation between pigment formation and mitochondrial degradation. Another factor that may be affected by lipofuscin is enzyme inhibition, that can strike enzymes such as vacuolar ATPase, which is responsible for lysossome acidification, a process that inhibits cell digestion as observed in zebra fish by Bibliowicz et al. (2011).

All these data show that a correlation between lipofuscin accumulation and cellular damage is already widely known and soundly based. Therefore, results obtained in the present study can be considered directly linked to the suppression of basic cellular functions. Our results also reveal that the tested contaminants triggered several reactions which resulted in problems of adaptation to environmental changes, even leading to more extreme cases of cell death and consequent loss of tissue mass in vital organs such as liver and gills.

Some curious results regarding lipofuscin in gills were obtained. For example, high numbers of inclusions after the first month of experiment in Astyanax altiparanae and greater amounts of pigment in Prochilodus lineatus of the control group than what was observed for specimens exposed to detergent after five months. Reversibility of lipopigment accumulation is not yet fully understood or proven, but recent studies have shown that in fish, up to $45 \%$ of lipopigment accumulation can be reverted due to recovery of lysosomal stability, knowing that the more polluted the area, the more efficient tissue regeneration gets (Au et al.). On the other hand, the possibility of oxidation and consumption of lipofuscin's lipid components and protein components cannot be discarded (Cunha et al., 1998).

Despite all claims, we do not believe that these last results are related to lysossomal reversibility, but rather, to tissue renewal. Gills are sites of direct exchanges with the environment and secondary lamellae have only one layer of epithelial cells, what results in quick wearing of cellular mechanisms and induces constant epithelial renewal. When the fish are exposed to pollutants, these regeneration processes must become even more efficient. This hypothesis is corroborated by the fact that one of the cases of higher pigment concentration occurred at the beginning of the experiment (one month of exposure), not after five months, what suggests that even under standard conditions, gill ageing and cellular degradation occur rapidly. Therefore, individuals exposed to contaminants that showed low concentration of lipofuscin probably did so because they were sampled shortly after cell renewal, as it happened to the group of Prochilodus lineatus exposed do detergent.

The use of at least two species is necessary to identify effects of pollutants, bearing in mind that other studies show that some fish species accumulate lipofuscin due to exposure to pollutants while others do not, as Viarengo et al. found in experiments conducted on the Ligurian sea in Italy.

\section{CONCLUSIONS}

Lipofuscin can be used as an environmental biomarker and the pollutants tested have been proven to affect fish physiology. Both detergent dilutions and urban lake waters generate cell imbalance leading to an increase in lipofuscin inclusions in gills and liver.

\section{ACKNOWLEDGMENTS}

The authors are thankful to FAPESP, process number: 2009/17118-9, for financial support and to ICMBio/CEPTA - Institute Chico Mendes for providing the specimens used in this experiment. - 
PEREIRA, B. F.; ALVES, A. L.; SENHORINI, J. A.; ROCHA, R. C. G. A.; PITOL, D. L. \& CAETANO, F. H. Efectos de detergentes biodegradables en la acumulación de lipofuscina (pigmento de envejecimiento) en branquias e hígado de dos especies de peces neotropicales. Int. J. Morphol., 32(3):773-781, 2014.

RESUMEN: Existe una preocupación creciente de la población y los gobiernos para identificar los efectos de substancias comúnmente arrojadas en ríos y lagos, sobre la fauna y flora acuática. El objetivo fue verificar los efectos de detergentes biodegradables y agua de un lago urbano sobre las branquias e hígado de dos especies de peces neo-tropicales de gran importancia económica, Astyanax altiparanae y Prochilodus lineatus. Analizamos los pigmentos de lipofuscina, también llamado pigmento de envejecimiento, el que fue utilizado como biomarcador. Después de uno y cinco meses de experimento, ambos tejidos acumulados con el pigmento fueron analizados. Los datos fueron discutidos desde el punto de vista fisiológico, relacionado con la peroxidación lipídica y daño mitocondrial.

PALABRAS CLAVE: Lipofuscina; Higado; Branquias; Prochilodus; Astyanax.

\section{REFERENCES}

Agius, C. \& Roberts, R. J. Melano-macrophage centres and their role in fish pathology. J. Fish Dis., 26(9):499-509, 2003.

Arking, R. Biologia do Envelhecimento: observações e princípios. 2nd ed. Riberão Preto, FUNPEC Editora, 2008.

$\mathrm{Au}, \mathrm{D}$. W. The application of histo-cytopathological biomarkers in marine pollution monitoring: a review. Mar. Pollut. Bull., 48(910):817-34, 2004.

Au, D. W.; Chen, P. \& Pollino, C. A. Cytological changes in association with ethoxyresorufin o-deethylase induction in fish upon dietary exposure to benzo[a]pyrene. Environ. Toxicol. Chem., 23(4):1043-50, 2004.

Banni, M.; Bouraoui, Z.; Ghedira, J.; Clearandeau, C.; Jebali, J. \& Bousseta, $\mathrm{H}$. Seasonal variation of oxidative stress biomarkers in clams Ruditapes decussatus sampled from Tunisian coastal areas. Environ. Monit. Assess., 155(1-4):119-28, 2009.

Bibliowicz, J.; Tittle, R. K. \& Gross, J. M. Toward a better understanding of human eye disease insights from the zebrafish, Danio rerio. Prog. Mol. Biol. Transl. Sci., 100:287-330, 2011.

Borucinska, J. D.; Kotran, K.; Shackett, M. \& Barker, T. Melanomacrophages in three species of free-ranging sharks from the northwestern Atlantic, the blue shark Prionacae glau$c a$ (L.), the shortfin mako, Isurus oxyrhinchus Rafinesque, and the thresher, Alopias vulpinus (Bonnaterre). J. Fish Dis., 32(19):883-91, 2009.

Cajaraville, M. P.; Cancio, I.; Ibabe, A. \& Orbea, A. Peroxisome proliferation as a biomarker in environmental pollution assessment. Microsc. Res. Tech., 61(2):191-202, 2003.

Couillard, C. M. \& Hodson, P. V. Pigmented macrophage aggregates: A toxic response in fish exposed to bleached-kraft mill effluent? Environ. Toxicol. Chem., 15(10):1844-54, 1996.

Cunha, D. F.; Pedrini, C. H.; Sousa, J. C.; Reis, M. A.; Ramos, S. G.; Cunha, S. F. C. \& Teixeira, V. P. A. Estudo Morfométrico do Miocárdio em Adultos com Subnutrição Protéico-Energética. Arq. Bras. Cardiol., 71(5):667-80, 1998.

Ding, L.; Kuhne, W. W.; Hinton, D. E.; Song, J. \& Dynan, W. S. Quantifiable biomarkers of normal aging in the Japanese medaka fish (Oryzias latipes). PLoS ONE., 5(10):e13287, 2010.

Han, J. \& Fang, Z. Estrogenic effects, reproductive impairment and developmental toxicity in ovoviparous swordtail fish (Xiphophorus helleri) exposed to perfluorooctane sulfonate (PFOS). Aquat. Toxicol., 99(2):281-90, 2010.

Hödl, E.; Felder, E.; Chabicovsky, M. \& Dallinger, R. Cadmium stress stimulates tissue turnover in Helix pomatia: increasing cell proliferation from metal tolerance to exhaustion in molluscan midgut gland. Cell Tissue Res., 341(1):159-71, 2010.

Jordanova, M.; Miteva, N. \& Rocha, E. A qualitative and quantitative study of the hepatic pigmented macrophage aggregates during the breeding cycle of Ohrid trout, Salmo letnica Kar. (Teloestei, Salmonidae). Microsc. Res. Tech., 71(11):822-30, 2008.

Junqueira, L. C. U. \& Junqueira, L. M. M. S. Técnicas básicas de citologia e histologia. São Paulo, Livraria e Editora Santos, 1983.

Kishi, S.; Bayliss, P. E.; Uchiyama, J.; Koshimizu, E.; Qi, J.; Nanjappa, P.; Imamura, S.; Islam, A.; Neuberg, D.; Amsterdam, A. \& Roberts, T. M. The identification of zebrafish mutants showing alterations in senescence-associated biomarkers.. PLOS Genet., 4(8):e1000152, 2008.

Kodama, K.; Yamakawa, T.; Shimizu, T. \& Aoki, I. Age estimation of the wild population of Japanese mantis shrimp Oratosquilla oratoria (Crustacea: Stomatopoda) in Tokyo Bay, Japan, using lipofuscin as an age marker. Fish. Sci., 71(1):141-50, 2005.

Machella, N.; Regoli, F. \& Santella, R. M. Immunofluorescent detection of 8-oxo-dG and PAH bulky adducts in fish liver 
and mussel digestive gland. Aquat. Toxicol., 71(4):335-43, 2005 .

Moore, M. N. Environmental stress signals: Cellular reactions to marine pollution. In: Graumann, W. \& Drukker, J. (Eds.). Histoand cytochemistry as a tool in environmental toxicology. New York, Fischer Verlag, 1991. pp.1-19.

Peixoto, S.; Aguado, N.; D’Incao, F.; Wasielesky, W. \& Cousin, J. C. Preliminary identification and quantification of the agepigment lipofuscin in the brain of Farfantepenaeus paulensis (Crustacea: Decapoda). Braz. J. Biol., 62(4B):871-6, 2002.

Pinto, A. L.; Varandas, S.; Coimbra, A. M.; Carrola, J. \& FontaínhasFernandes, A. Mullet and gudgeon liver histopathology and macroinvertebrate indexes and metrics upstream and downstream from a wastewater treatment plant (Febros River-Portugal). Environ. Monit. Assess., 169(1-4):569-85, 2010.

Radwan, M. A.; El-Gendy, K. S. \& Gad, A. F. Oxidative stress biomarkers in the digestive gland of Theba pisana exposed to heavy metals. Arch. Environ. Contam. Toxicol., 58(3):828-35, 2010.

Schutt, F.; Bergmann, M.; Holz, F. G. \& Kopitz, J. Proteins modified by malondialdehyde, 4-hydroxynonenal, or advanced glycation end products in lipofuscin of human retinal pigment epithelium. Invest. Ophthalmol. Vis. Sci., 44(8):3663-8, 2003.

Silva, M. M. \& Silva, V. H. Envelhecimento: importante fator de risco para o câncer. Arq. Med. ABC, 30(1):11-8, 2005.

Teh, S. J.; Adams, S. M. \& Hinton, D. E. Histopathologic biomarkers in feral freshwater fish populations exposed to different types of contaminant stress. Aquat. Toxicol., 37(1):5170, 1997.

Terzibasi, E.; Valenzano, D. R.; Benedetti, M.; Roncaglia, P.; Cattaneo, A.; Domenici, L. \& Cellerino, A. Large differences in aging phenotype between strains of the short-lived annual fish Nothobranchius furzeri. PLoS ONE, 3(12):e3866, 2008.

Terman, A. \& Brunk, U. T. Lipofuscin: mechanisms of formation and increase with age. A.P.M.I.S., 106(2):265-76, 1998.

Vaschenko, M. A.; Zhadan, P. M.; Aminin, D. L. \& Alyashova, T. N. Lipofuscin-like pigment in gonads of Sea Urchin Strongylocentrotus intermedius as a potential biomarker of marine pollution: a field study. Arch. Environ. Contam. Toxicol., 62(4):599-613, 2012.

Viarengo, A.; Dondero, F.; Pampanin, D. M.; Fabbri, R.; Poggi, E.; Malizia, M.; Bolognesi, C.; Perrone, E.; Gollo, E. \& Cossa, G. P. A biomonitoring study assessing the residual biological effects of pollution caused by the HAVEN wreck on marine organisms in the Ligurian Sea (Italy). Arch. Environ. Contam. Toxicol., 53(4):607-16, 2007.
Zhao, L.; Spassieva, S. D.; Jucius, T. J.; Shultz, L. D.; Shick, H. E.; Macklin, W. B.; Hannun, Y. A.; Obeid, L. M. \& Ackerman, S. L. A deficiency of ceramide biosynthesis causes cerebellar purkinje cell neurodegeneration and lipofuscin accumulation. PLoS Genet., 7(5):e1002063, 2011.

Correspondence to:

Dr. Dimitrius Leonardo Pitol

Faculdade de Odontologia de Ribeirão Preto FORP /USP

Departamento Morfologia Fisiologia e Patologia Básica

Avenida do Café S/N

Cep: 14040-904

Ribeirão Preto-SP

BRAZIL

Email: dimitrius@forp.usp.br

Received: 28-01-2014

Accepted: 22-05-2014 